\title{
PEMODELAN REGRESI SPASIAL PADA TPT DI DKI JAKARTA, JAWA BARAT, DAN BANTEN TAHUN 2018
}

\author{
Muhammad Suprapto' ${ }^{1}$, Gama Putra Danu Sohibien² \\ Politeknik Statistika STIS ${ }^{1}$ \\ Politeknik Statistika STIS² \\ Jalan Otista No.64C RT.1/RW.4, Bidara Cina, Jatinegara, Jakarta Timur. \\ 16.9306@stis.ac.id
}

\begin{abstract}
ABSTRAK
Pengangguran merupakan masalah utama yang dihadapi di berbagai negara baik negara maju maupun negara berkembang. Masalah pengangguran tidak terlepas kaitannya dengan dimensi wilayah atau dependensi spasial. Keberadaan dependensi spasial menunjukkan bahwa tingkat pengangguran di suatu wilayah akan berhubungan dengan tingkat pengangguran wilayah tetangganya. Penelitian ini bertujuan untuk memberikan gambaran umum Tingkat Pengangguran Terbuka (TPT) dan variabel-variabel yang diduga mempengaruhinya, mendapatkan model terbaik dalam menjelaskan pengaruh variabel-variabel independen terhadap TPT, dan menganalisis pengaruh variabel-variabel independen dari model terbaik terhadap TPT serta hubungan pengangguran antar wilayah. Analisis gambaran umum TPT dilakukan dengan pemetaan. Sedangkan untuk mendapatkan model terbaik dalam menjelaskan pengaruh variabel-variabel independen terhadap TPT diawali dengan pembentukan model regresi linier berganda. kemudian dilanjutkan dengan diagnosis keberadaan efek spasial dengan menggunakan Moran's I dan Lagrange Multiplier (LM) test. Model terbaik yang terbentuk adalah Spatial Lag Model dengan variabel independen yang signifikan. variabel-variabel independen yang mempengaruhi TPT di DKI Jakarta, Jawa Barat, dan Banten adalah persentase penduduk status kawin dan persentase penduduk miskin
\end{abstract}

Kata kunci: TPT, Moran's I, Lagrange Multiplier (LM), Spatial Lag Model

\begin{abstract}
Unemployment is a major problem faced in various countries both developed and developing countries. The problem of unemployment is inseparable with regard to the dimensions of region or spatial dependency. The existence of spatial dependency indicates that unemployment rate in a region will be related to unemployment rate of neighboring. This study aims to provide an overview unemployment rate (TPT) and independent variables expected influence it, get the best model in explaining impact of independent variables on TPT, and analyze impact of independent variables from the best model on TPT also unemployment reations between regions. TPT Visual analysis is done by mapping while to get the best model in explaining the influence of independent variables on TPT begins with the creation of a multiple linear regression models, Then proceed with the diagnosis of presence spatial effects by using the method of Moran's I and Lagrange Multiplier (LM) test. The spatial model formed is spatial lag model. The best model formed is Spatial Lag Model with significant independent variables. Social and population variables affecting TPT in Jakarta, West Java, and Banten are percentage of population's marital status and percentage of the poor population.
\end{abstract}

Keywords - TPT, Moran's I, Lagrange Multiplier (LM), Spatial Lag Model 


\section{PENDAHULUAN}

Pengangguran merupakan suatu kondisi negatif dimana jumlah kesempatan kerja tidak dapat mencukupi jumlah angkatan kerja, sehingga semakin banyak jumlah angkatan kerja yang tidak mendapatkan pekerjaan di suatu wilayah. Menurut Sukirno (2011) di kebanyakan negara masalah utama yang dihadapi adalah masalah pengangguran. Menurut Sri Budhi (2008) bahwa "negara manapun di dunia ini baik yang dikategorikan negara maju maupun negara berkembang senantiasa mengahadapi masalah pengangguran, perbedaannya negara berkembang tidak dapat mampu memberikan tunjangan kepada warga negaranya yang menganggur, sedangkan negara maju mampu memberikan jaminan itu".

Indikator pengangguran yang sering digunakan adalah Tingkat Pengangguran Terbuka (TPT). TPT di Indonesia tahun 2005-2018 cenderung mengalami penurunan jika dibandingkan dengan periode-periode sebelumnya. Berdasarkan Survei Angkatan Kerja Nasional (SAKERNAS) pada tahun 2005, TPT di Indonesia sebesar 11,24 persen, sedangkan pada Agustus 2018 mencapai mencapai 5,34 persen. Tingkat pengangguran di Indonesia cenderung mengalami penurunan, tetapi tingkat pengangguran di indonesia masih cukup tinggi jika dibandingkan dengan negaranegara lain di Asia Tenggara (ASEAN). Berdasarkan data International Monetary Fund (IMF) dalam world economic outlook april 2019 bahwa tingkat pengangguran indonesia pada tahun 2018 berbeda jauh jika dibandingkan dengan tingkat pengangguran di Malaysia (3,3 persen), Vietnam (2,2 persen), Singapura ( 2,1 persen), bahkan Thailand yang tingkat pengangguran mencapai 1,2 persen.

Indonesia merupakan negara kepulauan yang terdiri dari beberapa pulau besar antara lain pulau Jawa, Kalimantan, Sumatera, Sulawesi, Bali dan Nusa Tenggara, dan Maluku dan Papua. Pulau Jawa merupakan pusat pertumbuhan ekonomi di Indonesia dengan kontribusi Produk Domestik Regional Bruto (PDRB) terhadap PDB Nasional sebesar 58,49 persen. Hal ini memiliki arti bahwa setengah lebih kegiatan ekonomi di Indonesia berasal dari kegiatan ekonomi di pulau Jawa. Selain itu, realisasi investasi Penanaman Modal Asing (PMA) dan Penanaman Modal Dalam Negri (PMDN) di semua sektor didominasi oleh pulau Jawa. Akan tetapi hal tersebut tidak diikuti dengan pencapaian tenaga kerjanya. Berdasarkan data publikasi keadaan angkatan kerja di Indonesia, TPT di pulau Jawa mencapai 5,86 persen yang berada diatas TPT Nasional $(5,34)$. Jika dilihat menurut Provinsi, TPT di Pulau Jawa cenderung tinggi di Bagian Barat antara lain: Provinsi DKI Jakarta, Jawa Barat, dan Banten yang tingkat penganggurannya berada di atas tingkat pengangguran Nasional $(5,34)$, sedangkan di wilayah tengah dan timur pulau Jawa memiliki tingkat penganggurannya yang relatif rendah.

DKI Jakarta merupakan daerah yang menjadi pusat pemerintahan dan pusat bisnis. Sementara Jawa Barat dan Banten yang secara geografis letaknya berdampingan atau berdekatan dengan DKI Jakarta Sehingga provinsi Jawa Barat dan Banten memiliki kedekatan dalam pertumbuhan ekonomi dengan DKI Jakarta. Hal ini didukung juga dengan realisasi investasi PMA di pulau jawa didominasi oleh DKI Jakarta, Jawa Barat, dan Banten. Berdasarkan pernyataan diatas Seharusnya DKI Jakarta, Jawa Barat, dan Banten memiliki TPT yang rendah, tetapi kenyataannya tingkat penganggurannya masih tinggi jika dibandingkan dengan Nasional $(5,34)$. Kondisi ekonomi yang baik belum mampu mengatasi masalah tenaga kerja, hal ini dapat dimungkinkan adanya pengaruh dari variabel di luar ekonomi seperti variabel-variabel sosial dan kependudukan yang digunakan sebagai batasan variabel independen dalam penelitian ini.

Fenomena pengangguran ini merupakan masalah kompleks yang berat untuk diselesaikan oleh pemerintah, bahkan permasalahan ini masih berkelanjutan hingga saat ini. Sampai saat ini ada banyak kabupaten/kota di DKI Jakarta, Jawa Barat, dan Banten yang tingkat penganggurannya justru mengalami peningkatan. Untuk mengatasi masalah pengangguran di DKI Jakarta, Jawa Barat, dan Banten, baik pemerintah pusat maupun pemerintah daerah membutuhkan gambaran atau sebaran tingkat Pengangguran di level kabupaten/Kota sehingga dalam pelaksanaannya pemerintah lebih terfokus terhadap daerah-daerah mana saja yang membutuhkan perhatian lebih dalam masalah pengangguran. Dalam menyelesaikan masalah pengangguran pemerintah juga perlu mengetahui variabel-variabel apa saja yang berpengaruh signifikan terhadap tingkat pengangguran regional. Hal ini akan memberikan informasi atau 
masukan terhadap pemerintah pusat maupun pemerintah daerah sehingga solusi yang diambil bisa tepat sasaran.

Penelitain yang terkait dengan masalah pengangguran regional sudah dikemukakan oleh beberapa peneliti seperti yang dilakukan oleh Barret (2014) untuk mengetahui determinan dari tingkat pengangguran regional di inggris Sedangkan Aragon et al. (2003) menganalisis data level kabupaten di wilayah Midi-Pyrenees di Perancis. Banyak peneliti yang melakukan penelitian tentang fenomena pengangguran dalam suatu wilayah kesatuan misalnya di tingkat negara atau tingkat provinsi tanpa melibatkan efek ketergantungan wilayah. Beberapa peneliti menggunakan data panel untuk menganalisis fenomena pengangguran regional. Tidak sedikit pula peneliti menggunakan data cross section tanpa melibatkan interaksi spasial antar wilayah, namun penelitian tentang pengangguran yang melibatkan interaksi antar wilayah dengan menggunakan metode spasial masih sangat terbatas. Sedangkan menurut Molho (1995) bahwa Jika daerah mulai dengan pola tingkat pengangguran lokal yang stabil, setiap gangguan akan berdampak pada negara setempat dan berpengaruh ke daerah tetangga. Hal ini menunjukkan adanya ketergantungan tingkat pengangguran antar wilayah. Pengabaian ketergantungan antara daerah tetangga akan menyebabkan hasil regresi yang bias (Anselin, 1988).

Berdasarkan publikasi keadaaan angkatan kerja oleh BPS 2018, TPT kabupaten/kota di DKI Jakarta, Jawa Barat, dan Banten terdapat beberapa daerah yang jaraknya berdekatan/mengelompok memiliki TPT yang tidak berbeda jauh. Menurut Oktafianto (2019) bahwa "masalah pengangguran tidak terlepas dalam kaitannya dengan dimensi wilayah. Keberadaan dependensi spasial menunjukkan bahwa tingkat pengangguran regional di suatu wilayah akan berhubungan dengan wilayah tetangganya". Menurut lottman (2012) menyatakan bahwa "Menurut Teori ekonomi klasik menunjukkan bahwa perbedaan dalam pengangguran regional tidak boleh terjadi karena pengangguran yang tinggal di daerah dengan pengangguran tinggi diperkirakan pindah ke daerah dengan pengangguran yang lebih rendah". Berdasarkan permasalahan tingkat pengangguran yang telah dijelaskan, oleh karena itu penulis tertarik untuk meneliti tentang "Pengaruh variabel-variabel Sosial dan Kependudukan terhadap Tingkat Pengangguran Terbuka (TPT) di Provinsi DKI Jakarta, Jawa Barat, dan Banten tahun 2018 dengan pendekatan spasial".

Penelitian ini bertujuan untuk memberikan gambaran umum Tingkat Pengangguran Terbuka (TPT) dan variabel-variabel independent yang diduga mempengaruhinya, mendapatkan model terbaik dalam menjelaskan pengaruh variabel-variabel independen terhadap TPT, dan menganalisis pengaruh variabel-variabel independent terhadap TPT di DKI Jakarta, Jawa Barat serta hubungan pengangguran antar wilayah.

\section{METODE}

\subsection{LANDASAN TEORI \\ Teori Pengangguran}

Menurut Badan Pusat Statistik (BPS), "seseorang dikatakan menganggur apabila : (1) mereka yang tak punya pekerjaan dan mencari pekerjaan, (2) mereka yang tak punya pekerjaan dan mempersiapkan usaha, (3) mereka tak punya pekerjaan dan tidak mencari pekerjaan, karena merasa tidak mungkin mendapatkan pekerjaan, dan (4) mereka yang sudah punya pekerjaan, tapi belum mulai bekerja". Konsep dan definisi yang digunakan dalam statistik ketenagakerjaan mengacu pada The Labor Force Concept yang disarankan oleh International Labor Organization (ILO). International Labor Organization (ILO) menyatakan bahwa Tingkat pengangguran dihitung dengan menyatakan jumlah orang yang menganggur sebagai persentase dari jumlah total orang dalam angkatan kerja. hal serupa juga dinyatakan Badan Pusat Statistik (BPS) bahwa Tingkat Pengangguran Terbuka (TPT) merupakan persentase jumlah pengangguran terhadap jumlah angkatan kerja.

\section{Jumlah Penduduk}

Penduduk merupakan orang Indonesia maupun warga asing yang bertempat tinggal di Indonesia. Sedangkan, bukan penduduk merupakan orang asing yang tinggal di Indonesia dalam waktu singkat atau sementara sesuai Visa (Pasal 26 ayat 2 UUD 1945). Sedangkan menurut Badan 730 
Pusat Statistik (BPS), penduduk adalah semua orang yang berdomisili di wilayah geografis Republik Indonesia selama 6 bulan atau lebih dan atau mereka yang berdomisili kurang dari 6 bulan tetapi bertujuan untuk menetap. Dinamika Kendudukan dapat berdampak terhadap masalah ketenagakerjaan Menurut Azizah (2016) Maka akan mempengaruhi adanya tingkat pengangguran karena dengan meningkatnya jumlah pertumbuhan penduduk, maka jumlah tenaga kerja dan angkatan kerja juga ikut meningkat. Angkatan kerja membutuhkan lapangan pekerjaan dan umumnya di Negara berkembang laju pertumbuhan penduduk (termasuk angkatan kerja) lebih besar daripada laju pertumbuhan lapangan kerja. Oleh karena itu tidak semua angkatan kerja bisa mendapatkan pekerjaan dan akhirnya menganggur.

\section{Angkatan kerja Usia Tua (50 keatas)}

Struktur usia penduduk di suatu daerah dapat berpengaruh terhadap jumlah pengangguran di daerah yang bersangkutan melalui dampak yang ditimbulkan pada perilaku pencarian kerja. Menurut Barret (2014) bahwa pekerja yang lebih tua dalam angkatan kerja bisa juga penting karena pekerja yang lebih tua dapat memiliki pengalaman yang lebih besar dalam menjalani proses mencari pekerjaan yang telah dilakukan sebelumnya dalam kariernya. Hal ini bisa berarti peluang keberhasilan yang mereka rasakan lebih tinggi sehingga mereka dapat mencari pekerjaan yang lebih intensif dan, oleh karena itu daerah daerah dengan pekerja yang lebih tua dalam Angkatan kerja mengalami pengangguran yang lebih rendah.

\section{Penduduk Miskin}

Kemiskinan merupakan suatu kondisi ketidakmampuan atau keterbatasan dalam memenuhi kebutuhannya baik kebutuhan pokok maupun kebutuhan sekunder. Ketidakmampuan ini dapat berakibat terhadap turunya daya beli masyarakat yang akan menyebabkan keadaan perekonomian makro menjadi tidak stabil, sehingga dapat menyebabkan terbatasnya lapangan pekerjaan atau meningkatnya jumlah pengangguran. Hal ini sejalan dengan pendapat siyan,dkk (2016) bahwa masalah kemiskinan dapat berpengaruh terhadap inflasi dan tingkat pengangguran. Pemerintah harus berusaha untuk mengurangi tingkat kemiskinan dengan merumuskan dan mengimplementasikan program pengurangan kemiskinan seperti jaminan sosial, karena ini akan memberikan stabilitas ekonomi makro yang ditandai dengan menurunya inflasi dan tingkat pengangguran yang akan mengarah pada pertumbuhan ekonomi. Sehingga dengan mengurangi kemiskinan maka akan mengurangi inflasi dan tingkat pengangguran yang mengarah pada pertumbuhan ekonomi.

\section{Penduduk Status Kawin}

Status perkawinan penduduk menurut BPS terdiri dari: belum kawin, kawin, cerai hidup, dan cerai mati. Seseorang yang termasuk kategori kawin adalah mereka yang mempunyai pasangan perempuan (bagi laki-laki) atau pasangan laki-laki (bagi perempuan) tanpa terikat dalam perkawinan yang sah dalam hokum (adat, agama, negara), namun memiliki hubungan layaknya suami istri, baik tinggal bersama dalam satu rumah maupun tidak. Menurut Yuliatin,dkk (2011), Seorang kepala rumah tangga yang bertanggung jawab akan rela bekerja apa saja demi memenuhi nafkah keluarganya. Hal ini terkait juga dengan status perkawinannya, pada saat belum menikah masih ditampung keluarga dan setelah menikah harus mencari/membantu mencari nafkah untuk keluarga barunya sehingga menjadi pekerja.

\section{Regresi linier}

Regresi linier berganda merupakan analisis regresi linier yang digunakan untuk mengetahui bentuk/pola hubungan dan intensitas hubungan antara sebuah variabel dependen $(Y)$ dengan dua atau lebih variabel independen $(X)$ dan bertujuan untuk melakukan perkiraan/ramalan terhadap variabel dependen dari variabel independen. Secara umum, model regresi linier berganda dinyatakan sebagai berikut :

Keterangan :

$$
Y_{i}=\beta_{0}+\sum_{j=1}^{p} \beta_{j} X_{i j}+\varepsilon_{i} \quad ; j=1,2, \ldots, p
$$


$\mathrm{Y}_{\mathrm{i}} \quad$ : nilai variabel dependen pada amatan ke-i

$\mathrm{X}_{\mathrm{ij}} \quad$ : nilai variabel independen ke-j pada amatan ke-i

$\beta_{0} \quad$ : parameter intersep

$\beta_{\mathrm{j}} \quad$ : parameter koefisien regresi dari variabel independen ke-j (slope)

$\mathrm{p} \quad$ : banyaknya variabel independen

$\varepsilon_{\mathrm{i}} \quad$ : suku error

\section{Regresi Spasial}

Model yang dikembangkan oleh Anselin (1988) menggunakan data spasial cross section. Model spasial secara umum dapat dituliskan sebagai berikut :

$$
\begin{aligned}
& \mathbf{y}=\rho \mathbf{W}_{\mathbf{1}} \boldsymbol{y}+\mathbf{X} \boldsymbol{\beta}+\mathbf{u} \\
& \mathbf{u}=\lambda \mathbf{W}_{\mathbf{2}} \mathbf{u}+\boldsymbol{\varepsilon} \ldots \ldots \ldots \\
& \boldsymbol{\varepsilon} \sim \mathrm{N}\left(0, \sigma^{2} \mathbf{I}\right) \ldots \ldots \ldots \ldots
\end{aligned}
$$

Keterangan :

y : vektor variabel dependen, berukuran $(n \times 1)$

$\mathbf{X} \quad$ : matriks variabel independen, berukuran $(n \times p)$

$\boldsymbol{\beta} \quad$ : vektor parameter koefisien regresi, berukuran $(\mathrm{p} \times 1)$

$\rho \quad$ : parameter koefisien Spatial Lag pada variabel dependen

$\lambda \quad$ : parameter koefisien Spatial Error pada error $\mathrm{u}$

u : vektor error model umum, berukuran $(\mathrm{n} \times 1)$

$\boldsymbol{\varepsilon} \quad$ : vektor error model Spatial Error $(\mathrm{n} \times 1)$

$\mathbf{W}_{\mathbf{1}} \quad$ : matriks penimbang Spatial Lag (row standardized), berukuran ( $\left.\mathrm{n} \times \mathrm{n}\right)$

$\mathbf{W}_{2} \quad$ : matriks penimbang Spatial Error (row standardized), berukuran $(n \times n)$

I : matriks identitas, berukuran $(\mathrm{n} \times \mathrm{n})$

$\mathrm{n} \quad$ : jumlah amatan atau wilayah

\section{matriks penimbang}

Matriks penimbang yang digunakan dalam penelitian ini adalah penimbang customized berupa invers jarak suatu Kabupaten/Kota terhadap Kabupaten/Kota lainnya yang saling bersinggungan batas wilayahnya. penimbang customized lebih menggambarkan keadaan yang sebenarnya, sesuai dengan hukum Tobler dalam Anselin (1998) yang menyatakan bahwa "Everything is related to everything else, but near things are more related than distant things" yang artinya "Segala sesuatu memiliki hubungan dengan yang lainnya, akan tetapi sesuatu yang berdekatan akan memiliki hubungan yang lebih daripada sesuatu yang berjauhan". Perhitungan Invers Jarak suatu Kabupaten/Kota dengan pendekatan Haversine. Dengan rumus sebagai berikut :

Keterangan

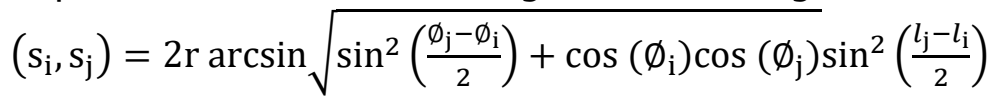

Keterangan :

r : Jari-jari

$\emptyset \quad$ : Titik Latitude

$l \quad$ : Titik Longitude

\subsection{METODE PENGUMPULAN DATA}

Penelitian ini mencangkup seluruh Kabupaten/Kota di provinsi DKI Jakarta, Jawa Barat dan Banten kecuali Kabupaten Kepulauan Seribu. Jumlah Kabupaten/Kota yang tercangkup sebanyak 40 Kabupaten/Kota yang terdiri dari 22 Kabupaten dan 18 Kota. Kabupaten Kepulauan Seribu tidak tercangkup sebagai unit analisis karena secara geografis wilayah tersebut tidak sesuai dengan model penimbang spasial yang digunakan. variabel independen yang digunakan merupakan variabel sosial dan kependudukan yaitu Persentase penduduk miskin, jumlah penduduk (dalam ribuan), persentase angkatan kerja usia tua (50 keatas) dan persentase penduduk berstatus kawin. Data yang digunakan dalam penelitian ini merupakan data sekunder level Kabupaten/Kota yang diperoleh dari publikasi Badan Pusat Statistik (BPS) tahun 2018. 


\subsection{METODE ANALISIS}

Metode analisis yang digunakan adalah analisis deskriptif dan analisis inferensia. Analisis Deskriptif bertujuan untuk menggambarkan pola sebaran spasial dari karakteristik TPT. Sedangkan analisis inferensia bertujuan untuk mengetahui pengaruh variabel sosial dan kependudukan terhadap TPT. Tahapan-tahapan dalam analisis inferensia, antara lain :

1. Menetapkan variabel dependen dan variabel-variabel independen

2. Membuat model regresi linier berganda untuk memodelkan hubungan antara variabel-variabel independen terhadap variabel dependen. Model umum regresi linier berganda adalah:

$$
y_{i}=\beta_{0}+\sum_{j=1}^{4} \beta_{j} x_{i j}+\varepsilon_{i}
$$

3. Melakukan uji asumsi error model regresi linier berganda

4. Melakukan uji autokorelasi/dependensi spasial menggunakan Moran's I, Jika terdapat autokorelasi/dependensi spasial, maka dilanjutkan dengan melakukan uji Lagrange Multiplier (LM) untuk menentukan Spatial Lag Model (SLM) atau Spatial Error Model (SEM). Model umum untuk Spatial Lag Model (SLM) adalah :

$$
\mathbf{y}=\rho \mathbf{W}_{1} \mathbf{y}+\mathbf{X} \boldsymbol{\beta}+\boldsymbol{\varepsilon}
$$

sedangkan model umum untuk Spatial Error Model (SEM) adalah :

$$
\mathbf{y}=\mathbf{X} \boldsymbol{\beta}+\mathbf{u} \text {, dimana } \mathbf{u}=\lambda \mathbf{W}_{\mathbf{2}}+\boldsymbol{\varepsilon}
$$

5. Melakukan uji heterogenitas spasial dengan Breusch Pagan Test. Jika ada heterogenitas spasial, maka dilanjutkan dengan pembentukan model GWR(Geoghrpically Weighted Regression). Model umum GWR adalah :

$$
\mathrm{y}_{\mathrm{i}}=\beta_{0}\left(\mathrm{u}_{\mathrm{i}}, \mathrm{v}_{\mathrm{i}}\right)+\sum_{\mathrm{k}=1}^{40} \beta_{\mathrm{k}}\left(\mathrm{u}_{\mathrm{i}}, \mathrm{v}_{\mathrm{i}}\right) \mathrm{x}_{\mathrm{ik}}+\varepsilon_{\mathrm{i}}
$$

6. Melakukan perbandingan antara model regresi linier berganda dan model regresi spasial

7. Melakukan uji asumsi terhadap model regresi yang terbaik

8. Interpretasi dari model terbaik yang diperoleh untuk menganalisis pengaruh sosial dan kependudukan terhadap Tingkat Pengangguran Terbuka (TPT) di DKI Jakarta, Jawa Barat, dan Banten tahun 2018.

\section{HASIL DAN PEMBAHASAN}

\subsection{GAMBARAN UMUM}

Peta sebaran spasial mengkategorikan TPT di level Kabupaten/Kota dengan menggunakan degradasi warna (hasil output dari software QGIS) yang menunjukkan besarnya nilai TPT, semakin gelap warna Kabupaten/Kota pada peta maka nilai TPT semakin tinggi, begitu pula sebaiknya. Kabupaten/Kota dengan TPT rendah cenderung mengelompok di bagian tenggara dan sedikit di bagian utara dengan nilai TPT kurang dari 6,60 persen yang terdiri dari empat Kabupaten yaitu Majalengka, Ciamis, Pangandaran, Bandung, dan enam Kotamadya antara lain Banjar, Jakarta Barat, Jakarta Pusat, Jakarta Selatan, Tangerang selatan, dan Depok sedangkan TPT tinggi mengelompok di bagian tengah dan sedikit di bagian barat laut. Nilai TPT dalam kategori tinggi $(9,70$ - 12,80) meliputi lima Kabupaten antara lain Serang, Bogor, Purwakarta, Ciancur,dan Cirebon. Sementara sebagian besar TPT menurut Kabupaten/Kota di DKI Jakarta, Jawa Barat, dan Banten dalam kategori sedang $(6,60-9,70)$. 


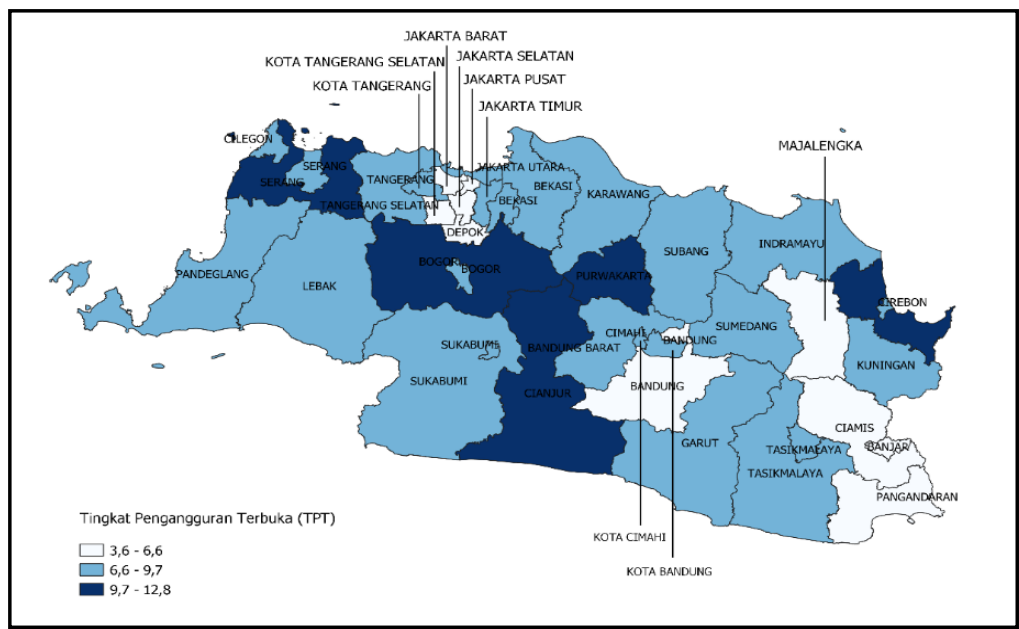

dan

Gambar 1. Peta sebaran TPT menurut Kabupaten/Kota di DKI Jakarta, Jawa Barat,

Banten tahun 2018.

\subsection{PEMODELAN TINGKAT PENGANGGURAN TERBUKA (TPT) REGRESI LINIER}

TPT dimodelkan dengan menggunakan regresi linier berganda secara parsial maupun serentak (overall). Secara parsial dilakukan untuk melihat kontribusi masing-masing variabel independen terhadap TPT. Sedangkan secara serentak untuk melihat pengaruh variabel independen secara keseluruhan terhadap TPT. Hasil uji parsial menunjukkan bahwa variabel jumlah penduduk (dalam ribuan) dan persentase penduduk miskin berpengaruh positif terhadap TPT. Sedangkan variabel persentase angkatan kerja usia tua (50 keatas) dan persentase penduduk berstatus kawin berpengaruh secara negatif terhadap TPT.

Hasil estimasi regresi linier berganda dengan semua variabel independen, didapatkan model sebagai berikut :

$$
\widehat{Y}=20,56+0,3777 \times 10^{-4} X_{1}-0,1429 X_{2}+0,3688 X_{3}^{*}-0,2009 X_{4}
$$

Keterangan :

*) signifikan pada $a=5$ persen

Model ini memiliki nilai Uji F sebesar 4,546 atau setara dengan p-value $=0,005$ (Tolak $\left.\mathrm{H}_{0}\right)$. Hal ini menunjukkan terdapat minimal satu variabel independen yang berpengaruh signifikan terhadap nilai TPT dengan taraf uji $a=5 \%$. Berdasarkan model regresi linier berganda dengan semua variabel independen terdapat satu variabel yang berpengaruh secara signifikan terhadap TPT yaitu variabel persentase penduduk miskin $\left(\mathrm{X}_{3}\right)$.

Berdasarkan hasil uji asumsi klasik menunjukkan bahwa model regresi linier berganda dengan semua variabel independen memenuhi semua asumsi klasik yaitu normalitas, nonautokorelasi, homoskedastis, dan multikolinieritas. Unit analisis yang digunakan dalam penelitian ini merupakan wilayah yaitu Kabupaten/Kota. Menurut Anselin (1988), apabila unit analisis berupa wilayah maka dimungkinkan terjadi autokorelasi spasial. Oleh karena itu, perlu dilakukan uji lanjutan sesuai dengan pendapat Anselin yaitu uji autokorelasi spasial.

Diagnosis keberadaan efek spasial melalui Moran's I dan Moran's Scatterplot menyatakan bahwa terdapat dependensi spasial/autokorelasi spasial. Berdasarkan hasil uji Lagrange Multiplier (LM) menunjukkan bahwa LM lag signifikan sedangkan LM error tidak signifikan pada taraf uji $a=$ $5 \%$. Sehingga dilanjutkan dengan pembentukan Spatial Lag Model dengan penimbang customized berupa invers jarak suatu Kabupaten/Kota terhadap Kabupaten/Kota lainnya yang saling bersinggungan batas wilayahnya. Sedangkan Hasil pengujian heterogenitas spasial (Breusch Pagan Test) menunjukkan bahwa tidak terdapat heterogenitas spasial pada TPT di DKI Jakarta, Jawa Barat, dan Banten 2018 sehingga tidak dilanjutkan pembentukan model GWR

\section{Regresi Spasial}

Hasil estimasi Spatial Lag Model (SLM) dengan semua variabel independen, didapatkan model sebagai berikut : 


$$
\begin{aligned}
& \widehat{\mathrm{Y}}_{i}=17,39384^{*}+0,30642 \sum_{j=1, i \neq j}^{40} \mathrm{w}_{i j} \mathrm{y}_{j}{ }^{*}+0,00016 \mathrm{X}_{1 i}-0,07999 \mathrm{X}_{2 i}+0,3003 \mathrm{X}_{3 i}{ }^{*}- \\
& 0,20874 \mathrm{X}_{4 i}{ }^{*}
\end{aligned}
$$

Keterangan :

*) signifikan pada $a=5$ persen

Berdasarkan model Spatial Lag Model (SLM) dengan semua variabel independen menunjukkan terdapat 2 variabel independen yang berpengaruh secara signifikan terhadap TPT yaitu persentase penduduk miskin $\left(\mathrm{X}_{3}\right)$ dan persentase penduduk berstatus kawin $\left(\mathrm{X}_{4}\right)$. Dilanjutkan dengan pembentukan Spatial Lag Model (SLM) dengan variabel independen yang signifikan.

Hasil estimasi Spatial Lag Model (SLM) dengan variabel independen yang signifikan, didapatkan model sebagai berikut :

$$
\widehat{\mathrm{Y}}_{i}=20,6956^{*}+0,3283 \sum_{j=1, i \neq j}^{40} \mathrm{w}_{i j} \mathrm{y}_{j}^{*}+0,2163 \mathrm{X}_{3 i}{ }^{*}-0,2834 \mathrm{X}_{4 i}{ }^{*}
$$

Keterangan :

*) signifikan pada $a=5$ persen

Berdasarkan model Spatial Lag Model (SLM) dengan variabel independen yang signifikan menunjukkan bahwa kedua variabel independen tetap berpengaruh secara signifikan terhadap TPT.

Pemilihan model terbalik dari beberapa model yang dihasilkan menggunakan kriteria Akaike Info Criterion (AIC) dan Schwarz Criterion (SC). Berikut ini merupakan nilai AIC dan SC dari beberapa model :

Tabel 1. Perbandingan nilai AIC dan SC dari beberapa model

\begin{tabular}{llcc}
\hline No. & Model & AIC & SC \\
\hline 1. & RLB dengan semua variabel X & 159,5627 & 169,696 \\
\hline 2. & SLM dengan semua Variabel X & 156,374 & 168,1962 \\
\hline 3. & SLM dengan Variabel X yang signifikan & $\mathbf{1 5 4 , 9 6 6 2}$ & $\mathbf{1 6 3 , 4 1 0 6}$
\end{tabular}

Sumber : BPS 2018 (diolah)

Berdasarkan Tabel 1 menujukkan model Spatial Lag Model (SLM) dengan variabel independen yang signifikan memiliki nilai AIC dan SC paling kecil jika dibandingkan dengan dua model lainnya. Hal ini menunjukkan bahwa Spatial Lag Model (SLM) dengan variabel independen yang signifikan merupakan model terbaik yang dapat menjelaskan pengaruh sosial dan kependudukan terhadap TPT di DKI Jakarta, Jawa Barat, dan Banten tahun 2018.

Model terbaik yang terbentuk memenuhi semua asumsi klasik yang meliputi normalitas, nonautokorelasi, homoskedastis. Dan nonmultikolinieritas. Lebih lanjut dilakukan uji likelihood Ratio (LR test) untuk menguji kesesuaian penggunaan model regresi spasial dibandingkan dengan model regresi OLS. Hasil uji LR menunjukkan nilai p-value sebesar 0,01217. Hal ini menunjukkan model terbaik yang terbentuk (Spatial Lag Model dengan variabel independen yang signifikan) lebih baik dari pada model regresi OLS. Model terbaik yang terbentuk sebagai berikut :

$$
\widehat{\mathrm{Y}}_{i}=20,6956^{*}+0,3283 \sum_{j=1, i \neq j}^{40} \mathrm{w}_{i j} \mathrm{y}_{j}{ }^{*}+0,2163 \mathrm{X}_{3 i}{ }^{*}-0,2834 \mathrm{X}_{4 i}{ }^{*}
$$

Keterangan :

*) signifikan pada $\mathrm{a}=5$ persen

Dari model terbaik tersebut dapat diinterpretasikan :

a. Persentase penduduk miskin berpengaruh positif dan signifikan terhadap TPT dalam taraf uji 5 persen. Setiap kenaikan satu persen persentase penduduk miskin di masing-masing Kabupaten/Kota maka akan menaikkan TPT sekitar 0,2163 persen dengan asumsi variabel lain dianggap konstan.

b. Persentase penduduk berstatus kawin berpengaruh negatif dan signifikan terhadap TPT dalam taraf uji 5 persen. Setiap kenaikan satu persen persentase penduduk berstatus kawin di masing-masing Kabupaten/Kota maka akan menurunkan TPT sekitar 0,2834 persen dengan asumsi variabel lain dianggap konstan. 
c. Berdasarkan persamaan Lag yang dihasilkan, TPT suatu Kabupaten/Kota mengalami kenaikan sebesar 0,3283 kali pembobot spasial tiap Kabupaten/Kota apabila jumlah variabel lag Kabupaten/Kota tetangganya meningkat satu persen. Sebagai contoh, Kabupaten Bekasi memiliki pembobot spasial dengan wilayah tetangganya (Jakarta Timur, Jakarta Utara, Bogor, Karawang, dan Kota Bekasi) dengan nilai berbeda-beda tergantung dengan jarak antar wilayah.

$$
\widehat{\mathrm{Y}}_{\text {Bekasi }}=0,3283 \sum_{j=1, i \neq j}^{5} \mathrm{w}_{i j} \mathrm{y}_{i}
$$

Yang dapat di tulis secara lengkap, sebagai berikut :

$$
\begin{array}{r}
\widehat{\mathrm{Y}}_{\text {Bekasi }}=0,071 \mathrm{y}_{\text {Jakarta Timur }}+0,0586 \mathrm{y}_{\text {Jakarta Utara }}+0,0321 \mathrm{y}_{\text {Bogor }}+ \\
0,067 \mathrm{y}_{\text {Karawang }}+0,0996 \mathrm{y}_{\text {Kota Bekasi }}+\ldots \ldots \ldots \ldots \ldots \ldots \ldots \ldots \ldots \ldots \ldots \ldots \ldots \ldots \ldots \ldots \ldots
\end{array}
$$

Berikut merupakan contoh model regresi terbaik atau Spatial Lag Model (SLM) dengan variabel independen yang signifikan untuk Kabupaten Bekasi.

$$
\begin{aligned}
& \widehat{\mathrm{Y}}_{\text {Bekasi }}=20,6956+0,071 \mathrm{y}_{\text {Jakarta Timur }}+0,0586 \mathrm{y}_{\text {Jakarta Utara }}+0,0321 \mathrm{y}_{\text {Bogor }}+ \\
& 0,067 \mathrm{y}_{\text {Karawang }}+0,0996 \mathrm{y}_{\text {Kota Bekasi }}+0,2163 \mathrm{X}_{3 \text { Bekasi }}-0,2834 \mathrm{X}_{4 \text { Bekasi }} \\
& \ldots \ldots \ldots \ldots \ldots \ldots . . .(16)
\end{aligned}
$$

\section{KESIMPULAN}

Gambaran umum dari variabel TPT dan variabel independen menunjukkan adanya dependesi spasial bahwa Kabupaten/Kota yang daerahnya berdekatan memiliki nilai karakteristik yang mirip dan cenderung mengelompok. Spatial Lag Model (SLM) dengan variabel independen persentase penduduk miskin dan persentase penduduk berstatus kawin di masing-masing Kabupaten/Kota merupakan model terbaik yang dapat menjelaskan TPT di DKI Jakarta, Jawa Barat, dan Banten tahun 2018. Semakin tinggi persentase penduduk miskin dan semakin rendah persentase penduduk berstatus kawin di masing-masing Kabupaten/Kota maka akan meningkatkan TPT masing-masing Kabupaten/Kota di DKI Jakarta, Jawa Barat, dan Banten tahun 2018.

\section{DAFTAR PUSTAKA}

Anselin, Luc and A. Bera. (1998). Spatial Dependence in Linear Regression Models with an Introduction to Spatial Econometrics. Handbook of Applied Economic Statistics, 237- 289. New York: Marcel Dekker.

Anselin, Luc. (1988). Spatial Econometrics : Methods and Models. Santa Barbara : Kluwer Academic Publisher.

Anselin, Luc. (1995). Local Indicators Of Spatial Association-LISA. Ohio State University Press.

Anselin, Luc. (1996). Spatial Econometrics. University of Texas in Dallas.

Aragon, Yves dkk. (2003). Explaining the Pattern of Regional Unemployment. The Case of the Midi-Pyerenees Region. Paper in Regional Science.

Aryati, Fitri, dkk. (2014). Analisis Pengangguran Terdidik Di Provinsi Bengkulu. Jurnal Ekonomi dan Perencanaan Pembangunan (JEPP). 5(4).

Azizah, F. I. (2016). Analisis Pengaruh Jumlah Penduduk Pertumbuhan Ekonomi Dan Inflasi Terhadap Pengangguran Terbuka. Jurnal Universitas Sunan Kali Jaga.

Budiarto dan Munir, (1985). Teknik Analisa Kependudukan. Rineka Cipta. Jakarta. 
Badan Pusat Statistik. (2018). Berita Resmi Statistik Keadaan Angkatan Kerja Indonesia Agustus 2018. Jakarta: BPS.

Badan Pusat Statistik. (2019). Publikasi Produk Domestik Regional Bruto Provinsi-Provinsi Di Indonesia Menurut Lapangan Usaha 2014-2018. Jakarta: BPS.

Badan Pusat Statistik. (2019). Publikasi Keadaan Angkatan Kerja Di Indonesia Agustus 2018. Jakarta: BPS

Badan Pusat Statistik. (2019). Statistik Indonesia 2019. Jakarta:BPS.

Badan Pusat Statistik Provinsi DKI Jakarta. (2019). Provinsi DKI Jakarta Dalam Angka 2019. DKI Jakarta: BPS.

Badan Pusat Statistik Provinsi Jawa Barat. (2019). Provinsi Jawa Barat Dalam Angka 2019. Jawa Barat: BPS.

Badan Pusat Statistik Provinsi Banten. (2019). Provinsi Banten Dalam Angka 2019. Banten: BPS.

Barrett, A. (2014). Spatial Dependence in Unemployment in Great Brittain. Tesis. Netherland (NED): Eramus University Rotterdam.

Blanchard, O J dan Lawrence F K. (1992). Regional Evolution. Brookings Papers on Economic Policy, January.

Lottmann, Franziska. (2012). Explaining Regional Differences Unemployment in Germany, A Spatial Panel Data Analysis. Discussion Paper No.26, SFB 649.

Mankiw,N Greogory. (2008). Makroekonomi Edisi Ketujuh. Jakarta : Erlangga.

Molho, Ian. (1995). Spatial Autocorrelation in British unemployment. Journal of Regional Studies. Vol: 35(4).

Muslim, Mohammad Rifqi. (2014). Pengangguran Terbuka dan Determinannya. Jurnal Ekonomi dan Studi Pembangunan: Institute of Public Policy and Economic Studies (INSPECT) Yogyakarta.

Oktafianto, E K. (2019). Determinan Pengangguran Regional Di Indonesia: Model Spasial Durbin. Tesis, Ilmu Ekonomi. Bogor: Institut Pertanian Bogor(IPB).

Pramusinta, Elsa Betha. (2012). Analisis Hubungan Antara Pertumbuhan Penduduk dan Dependency Ratio Dengan Pertumbuhan Ekonomi Kota Semarang Pada Tahun 1986-2008. Skripsi. Semarang. Fakultas Ekonomi Universitas Diponegoro.

Siregar, Hermanto dan Dwi Wahyuniarti. (2008). Dampak Pertumbuhan Ekonomi Terhadap Penurunan Jumlah Penduduk Miskin. Jurnal Kajian Ekonomi dan Lingkungan.

Siyan, dkk. (2016). Unemployment and Inflation: Implication on Poverty Level in Nigeria. Munich Personal RePEc Archive.

Sri Budhi, Made Kembar. (2008). Mengelola Sumber Daya Manusia Menyongsong Millenium Development Goals (MDGs). Jurnal Ekonomi dan Sosial, h: 82-85.

Sukirno, Sadono. (2011). Makro Ekonomi Teori Pengantar, Edisi Ketiga. Jakarta:Rajawali Pers.

Wahyuni, Daru. (2005). Peran Sektor Informal Dalam Menanggulangi Masalah Pengangguran di Indonesia. Jurnal Economia. Vol. 1. No. 1. 
Yuliatin, dkk. (2011). Pengaruh Karakteristik Kependudukan Terhadap Pengangguran Di Sumatera Barat. Jurnal Manajemen dan Kewirausahaan. 2(2). 